\title{
Kurikulum Terintegrasi di Pondok Pesantren Annida Al Islamy Bekasi
}

\section{Wathroh Mursyidi}

STIT Al Marhalah Al Ulya Bekasi

Email: wawahsholeh@gmail.com

\begin{abstract}
The institution of education that allows for formal, informal, even non formal learning is also a boarding school. In its history, the direct correlation between the boarding schoool, families and communities and even the state has been going on for four centuries. One thing the boarding school then needs is to formulate a clear curriculum that can cover all forms and educational environment. The boarding school of Annida Al Islamy Bekasi is one of the oldest educational institutions in the city of bekasi, located in center of bekasi That still tries to keep up the boarding school tradition by adjusting the needs of the globalization era. For one thing, by undertaking the integration of the educational system in particular terms of developing the curriculum. Through the curriculum it is expected to contribute to the education effort for individuals to become humans and to become ulul al baab generation, fostered, guided, and condemned with syari 'at and kaidahbased islamic by the kiai, asatidz, and the masters at boarding school with the highlighted character of Islam as rahmatan lil 'aalamin.
\end{abstract}

Keywords: Curriculum, Integration, Boarding School. 


\section{Pendahuluan}

Pondok Pesantren adalah lembaga pendidikan Islam tertua yang merupakan produk budaya Indonesia. Keberadaan Pesantren di Indonesia dimulai sejak Islam masuk negeri ini dengan mengadopsi sistem pendidikan keagamaan yang sebenarnya telah lama berkembang sebelum kedatangan Islam.Sebagai lembaga pendidikan yang telah lama berurat akar di negeri ini, pondok pesantren diakui memiliki andil yang sangat besar terhadap perjalanan sejarah bangsa. ${ }^{1}$

Pondok Pesantren merupakan dua istilah yang menunjukkan satu pengertian. Pesantren menurut pengertian dasarnya adalah tempat belajar para santri, sedangkan pondok berarti rumah atau tempat tinggal sederhana terbuat dari bambu. Di samping itu, kata pondok mungkin berasal dari Bahasa Arab Funduq yang berarti asrama atau hotel. Di Jawa termasuk Sunda dan Madura umumnya digunakan istilah pondok dan pesantren, sedang di Aceh dikenal dengan Istilah dayah atau rangkang atau menuasa, sedangkan di Minangkabau disebut surau. ${ }^{2}$ Pesantren juga dapat dipahami sebagai lembaga pendidikan dan pengajaran agama, umumnya dengan cara nonklasikal, di mana seorang kiai mengajarkan ilmu agama Islam kepada santri-santri berdasarkan kitab-kitab yang ditulis dalam bahasa Arab oleh Ulama Abad pertengahan, dan para santrinya biasanya tinggal di pondok (asrama) dalam pesantren tersebut.

Pondok Pesantren di Indonesia memiliki peran yang sangat besar, baik bagi kemajuan Islam itu sendiri maupun bagi bangsa Indonesia secara keseluruhan. Berdasarkan catatan yang ada, kegiatan pendidikan agama di Nusantara telah dimulai sejak tahun 1596. Kegiatan agama inilah yang kemudian dikenal dengan nama Pondok Pesantren. Bahkan dalam

\footnotetext{
${ }^{1}$ Haedari, H.Amin. Transformasi Pesantren, (Jakarta: Media Nusantara, 2007), hlm. 3

${ }^{2}$ Nurcholis Madjid, Bilik-Bilik Pesantren Sebuah Potret Perjalanan, (Jakarta: Paramadina, 1997), hlm. 5$$
\text { - } 146 \text { - }
$$

Al Marhalah : Jurnal Pendidikan Islam. Volume. 14, No. 2 November 2018 
catatan Howard M. Federspiel- salah seorang pengkaji keislaman di Indonesia, menjelang abad ke-12 pusat-pusat studi di Aceh (pesantren disebut dengan nama Dayah di Aceh) dan Palembang (Sumatera), di Jawa Timur dan di Gowa (Sulawesi) telah menghasilkan tulisan-tulisan penting dan telah menarik santri untuk belajar. ${ }^{3}$

Pondok pesantren adalah lembaga pendidikan Islam yang diperkenalkan di jawa sekitar 500 tahun yang lalu. Sejak saat itu, lembaga pesantren telah mengalami banyak perubahan dan memainkan peran dalam masyarakat Indonesia. Pada zaman wali songo, pondok pesantren memainkan peran penting dalam penyebaran agama Islam di pulau Jawa. Juga pada zaman penjajahan Belanda , hampir semua peperangan melawan pemerintah kolonial Belanda bersumber atau paling tidak mendapat dukungan sepenuhnya dari pesantren.

Istilah pesantren berasal dari kata pe-santri-an, di mana kata "santri" berarti murid dalam Bahasa Jawa. Istilah pondok berasal dari Bahasa Arab funduuq (فندوق) yang berarti penginapan. Khusus di Aceh, pesantren disebut juga dengan nama dayah. Biasanya pesantren dipimpin oleh seorang Kyai. Untuk mengatur kehidupan pondok pesantren, kyai menunjuk seorang santri senior untuk mengatur adik-adik kelasnya, mereka biasanya disebut lurah pondok. Tujuan para santri dipisahkan dari orang tua dan keluarga mereka adalah agar mereka belajar hidup mandiri dan sekaligus dapat meningkatkan hubungan dengan kyai dan juga Tuhan.

Pendapat lainnya, pesantren berasal dari kata santri yang dapat diartikan tempat santri Kata santri berasal dari kata Cantrik (bahasa Sansakerta, atau mungkin Jawa) yang berarti orang yang selalu mengikuti guru, yang kemudian dikembangkan oleh Perguruan Taman Siswa dalam

\footnotetext{
${ }^{3}$ Hielmy, Irfan. Wancana Islam (ciamis:Pusat Informasi Pesantren,2000), hal. 120
} 
sistem asrama yang disebut Pawiyatan. Istilah santri juga dalam ada dalam bahasa Tamil, yang berarti guru mengaji, sedang C. C Berg berpendapat bahwa istilah tersebut berasal dari istilah shastri, yang dalam bahasa India berarti orang yang tahu buku-buku suci agama Hindu atau seorang sarjana ahli kitab suci agama Hindu Terkadang juga dianggap sebagai gabungan kata saint (manusia baik) dengan suku kata tra (suka menolong), sehingga kata pesantren dapat berarti tempat pendidikan manusia baik-baik. ${ }^{4}$

Elemen dasar suatu pesantren meliputi; pondok pesantren (tempat tinggal), santri, kyai, masjid, dan pengajaran kitab-kitab klasik. Sejak tumbuhnya pesantren, pengajaran kitab-kitab klasik diberikan sebagai upaya untuk meneruskan tujuan utama pesantren yaitu mendidik calon-calon ulama yang setia terhadap paham Islam tradisional. Karena itu kitab-kitab Islam klasik merupakan bagian integral dari nilai dan paham pesantren yang tidak dapat dipisah-pisahkan.

Penyebutan kitab-kitab Islam klasik di dunia pesantren lebih populer dengan sebutan "kitab kuning", tetapi asal usul istilah ini belum diketahui secara pasti. Mungkin penyebutan istilah tersebut guna membatasi dengan tahun karangan atau disebabkan warna kertas dari kitab tersebut berwarna kuning, tetapi argumentasi ini kurang tepat sebab pada saat ini kitab-kitab Islam klasik sudah banyak dicetak dengan kertas putih.

Pengajaran kitab-kitab Islam klasik oleh pengasuh pondok (Kyai) atau ustaz biasanya dengan menggunakan sistem sorogan, wetonan, dan bandongan. Adapun kitab-kitab Islam klasik yang diajarkan di pesantren menurut Zamakhsyari Dhofir dapat digolongkan ke dalam 8 kelompok, yaitu: (1) Nahwu (syntax) dan Sharaf (morfologi), (2) Fiqih (hukum), (3) Ushul Fiqh (yurispundensi), (4) Hadits, (5) Tafsir, (6) Tauhid (theologi), (7)

\footnotetext{
${ }^{4}$ Fatah, H Rohadi Abdul, Taufik, M Tata, Bisri, Abdul Mukti. Rekontruksi Pesantren Masa Depan, (Jakarta Utara: PT. Listafariska Putra, 2005), hlm. 11

- 148 -
}

Al Marhalah : Jurnal Pendidikan Islam. Volume. 14, No. 2 November 2018 
Tasawuf dan Etika, (8) Cabang-cabang lain seperti Tarikh (sejarah) dan Balaghah"

Kitab-kitab Islam klasik adalah kepustakaan dan pegangan para Kyai di pesantren. Keberadaannya tidaklah dapat dipisahkan dengan Kyai di pesantren. Kitab-kitab Islam klasik merupakan modifikasi nilai-nilai ajaran Islam, sedangkan Kyai merupakan personifikasi dari nilai-nilai itu. Di sisi lain keharusan Kyai di samping tumbuh disebabkan kekuatan-kekuatan mistik yang juga karena kemampuannya menguasai kitab-kitab Islam klasik.

Sehubungan dengan hal ini, Moh. Hasyim Munif mengatakan bahwa: "Ajaran-ajaran yang terkandung dalam kitab kuning tetap merupakan pedoman hidup dan kehidupan yang sah dan relevan. Sah artinya ajaran itu diyakini bersumber pada kitab Allah Al-Qur'an dan sunnah Rasulullah (AlHadits), dan relevan artinya ajaran-ajaran itu masih tetap cocok dan berguna kini atau nanti”. Dengan demikian, pengajaran kitab-kitab Islam klasik merupakan hal utama di pesantren guna mencetak alumnus yang menguasai pengetahuan tentang Islam bahkan diharapkan di antaranya dapat menjadi Kyai.

Dua model pembelajaran yang terkenal pada awal mula berdirinya pesantren adalah model sistem pembelajaran wetonan non klasikal dan sistem sorogan. Sistem wetonan/bandongan adalah pengajian yang dilakukan oleh seorang kiai yang diikuti oleh santrinya dengan tidak ada batas umur atau ukuran tingkat kecerdasan. Sistem pembelajaran model ini, kabarnya merupakan metode yang diambil dari pola pembelajaran ulama Arab. Sebuah kebiasaan pengajian yang dilakukan di lingkungan Masjid al-Haram. Dalam sistem ini, seorang kiai membacakan kitab, sementara para santri masingmasing memegang kitab sendiri dengan mendengarkan keterangan guru untuk mengesahi atau memaknai Kitab Kuning. 
Lain dengan pengajian wetonan, pengajian sorogan dilakukan satu persatu, dimana seorang santri maju satu persatu membaca kitab dihadapan kiai untuk dikoreksi kebenaannya. Pada pembelajaran sorogan ini, seorang santri memungkinkan untuk berdialog dengan kiai mengenai masalahmasalah yang diajarkan. Sayangnya banyak menguras waktu dan tidak efesien sehingga diajarkan pada santri-santri senior saja.

Pendidikan pondok pesantren yang merupakan bagian dari Sistem Pendidikan Nasional memiliki 3 unsur utama yaitu:

1) Kyai sebagai pendidik sekaligus pemilik pondok dan para santri;

2) Kurikulum pondok pesantren; dan

3) Sarana peribadatan dan pendidikan, seperti masjid, rumah kyai, dan pondok, serta sebagian madrasah dan bengkel-bengkel kerja keterampilan.

Kegiatannya terangkum dalam "Tri Dharma Pondok pesantren" yaitu:

1) Keimanan dan ketaqwaan kepada Allah SWT;

2) Pengembangan keilmuan yang bermanfaat; dan

3) Pengabdian kepada agama, masyarakat, dan negara.

Pada awal abad kedua puluhan, unsur baru berupa sistem pendidikan klasikal mulai memasuki pesantren. Sejalan dengan perkembangan dan perubahan bentuk pesantren, Menteri Agama RI. Mengeluarkan peraturan nomor 3 tahun 1979, yang mengklasifikasikan pondok pesantren sebagai berikut:

1. Pondok Pesantren tipe A, yaitu dimana para santri belajar dan bertempat tinggal di Asrama lingkungan pondok pesantren dengan pengajaran yang berlangsung secara tradisional (sistem wetonan atau sorogan).

2. Pondok Pesantren tipe $B$, yaitu yang menyelenggarakan pengajaran secara klasikal dan pengajaran oleh kyai bersifat aplikasi, diberikan -150 -

Al Marhalah : Jurnal Pendidikan Islam. Volume. 14, No. 2 November 2018 
pada waktu-waktu tertentu. Santri tinggal di asrama lingkungan pondok pesantren.

3. Pondok Pesantren tipe $\mathrm{C}$, yaitu pondok pesantren hanya merupakan asrama sedangkan para santrinya belajar di luar (di madrasah atau sekolah umum lainnya), kyai hanya mengawas dan sebagai pembina para santri tersebut.

4. Pondok Pesantren tipe D, yaitu yang menyelenggarakan sistem pondok pesantren dan sekaligus sistem sekolah atau madrasah.

Peraturan Pemerintah, dalam hal ini Menteri Agama yang mengelompokkan pesantren menjadi empat tipe tersebut, bukan suatu keharusan bagi pondok pesantren tersebut. Namun, pemerintah menyikapi dan menghargai perkembangan serta perubahan yang terjadi pada pondok pesantren itu sendiri, walaupun perubahan dan perkembangan pondok pesantren tidak hanya terbatas pada empat tipe saja, namu akan lebih beragam lagi. Dari tipe yang sama akan terdapat perbedaan-perbedaan tertentu yang menjadikan satu sama lain akan berbeda.

Populasi pondok pesantren ini semakin bertambah dari tahun ke tahun, baik pondok pesantren tipe salafiyah maupun khalafiyah yang kini tersebar di penjuru tanah air. Pesatnya pertumbuhan pesantren ini akan sekan mendorong pemerintah untuk melembagakannya secara khusus. Sehingga keluarlah surat keputusan Menteri Agama Republik Indonesia nomor 18 tahun 1975 tentang susunan organisasi dan tata kerja Departemen agama yang kemudian diubah dan disempurnakan dengan keputusan Menteri Agama RI nomor 1 tahun 2001.

Dengan keluarnya surat keputusan tersebut, maka pendidikan pesantren dewasa ini telah mendapatkan perhatian yang sama dari pemerintah terutama Departemen Agama. Saat ini telah menjadi direktorat tersendiri yaitu direktorat pendidikan keagamaan dan pondok pesantren yang bertujuan 
Wathroh Mursyidi

untuk meningkatkan pelayanan pondok pesantren secara optimal terhadap masyarakat.

Pendidikan pesantren termasuk jenis pendidikan keagamaan. Pendidikan keagamaan merupakan pendidikan yang sedemikian rupa menyiapkan peserta didik untuk dapat menjalankan perannya sebagai warga negara dengan dasar penguasaan pengetahuan khusus ajaran agama yang bersangkutan (UU No 20/2003: pasal 11 ayat (6). Peraturan Pemerintah Republik Indonesia Nomor 55 Tahun 2007 tentang Pendidikan Agama dan Keagamaan pasal 14 menyatakan bahwa pendidikan keagamaan Islam dapat berbentuk pendidikan diniyah dan pesantren. Ayat (3) dalam peraturan pemerintah tersebut menjelaskan bahwa pesantren dapat menyelenggarakan satu atau berbagai satuan dan/atau program pendidikan pada jalur formal, nonformal, dan informal. Artinya, pendidikan pesantren dapat mengintegrasikan program pada jalur formal, nonformal, dan informal. Pasal 13 ayat (4) menjelaskan tentang syarat pendirian satuan pendidikan keagamaan sebagaimana yang dimaksud pada ayat (3) yakni terdiri atas: isi pendidikan, jumlah dan kualifikasi pendidik dan tentang kependidikan, sarana dan prasarana yang memungkinkan terselenggaranya kegiatan pembelajaran, sumber pembiayaan untuk kelangsungan program pendidikan sekurang-kurangnya untuk satu tahun pendidikan/akademik berikutnya, sistem evaluasi, dan manajemen dan proses pendidikan.

Program pada jalur formal, pendidikan keagamaan mencakup pendidikan diniyah dan pendidikan pesantren. Pasal 15 peraturan pemerintah di atas menyatakan bahwa pendidikan diniyah formal menyelenggarakan pendidikan ilmu-ilmu yang bersumber dari ajaran agama Islam pada jenjang Pendidikan Anak Usia Dini (PAUD), pendidikan dasar, pendidikan menengah, dan pendidikan tinggi, serta pendidikan diniyah nonformal. Pada pasal 21 ditetapkan bahwa pendidikan diniyah nonformal diselenggarakan -152 -

Al Marhalah : Jurnal Pendidikan Islam. Volume. 14, No. 2 November 2018 
dalam bentuk pengajian kitab, majelis taklim, Pendidikan al-Quran, diniyah takmiliyah, atau bentuk lain yang sejenis. Berarti pendidikan pesantren dapat menyelenggarakan program pendidikan jalur formal, wajib belajar 9 tahun dan menengah seperti pada madrasah dan sekolah. Pendidikan pesantren dapat pula menyelenggarakan program pendidikan keagamaan dengan jenis pendidikan diniyah formal dan jenis pendidikan diniyah nonformal.

Menurut Beauchamp Kurikulum adalah "A curriculum is a written document which may contain many ingredients, but basically it is a plan for the education of pupils during theie enrollment in given school". Beauchamp lebih memberikan tekanan bahwa kurikulum adalah suatu rencana pendidikan atau pengajaran. ${ }^{5}$

Kurikulum merupakan salah satu bagian dari keberlangsungan proses pendidikan yang sangat penting. Kurikulum dalam pendidikan menjadi acuan dasar yang mengarah kepada tujuan kegiatan pendidikan yang sedang atau akan dilaksanakan. Kurikulum dalam pendidikan Islam khususnya mencakup seluruh aspek kehidupan manusia, baik yang berkaitan dengan jasmaninya dan rohaninya. Dalam pendidikan Islam sumber ajaran atau materi yang di aplikasikan menjadi suatu kurikulum adalah Al Quran dan As Sunnah, kemudian dikategorikan dalam ilmu-ilmu yang berisi tentang manusia (al'Ulum al- Insaniyah), dan ilmu-ilmu yang berisi tentang alam semesta (al'Ulum al-Kauniyah). Pengkategorian tersebut semata-mata bukan untuk membagi-bagi ilmu dalam kotak-kotak tertentu, karena pada dasarnya semua ilmu yang ada didunia ini terinspirasi dari sumber yang sama yaitu Al-Quran dan As-sunnah. Maka kurikulum yang baik dalam upaya meraih tujuan pendidikan dalam Islam yaitu Insan Kamil adalah pengintegrasian kurikulum yang komprehensif dan holistik mencakup ilmu agama dan ilmu umum.

\footnotetext{
5 Nana Syaodih Sukmadinata, Pengembangan Kurikulum: Teori dan Praktek, (Bandung: Remaja Rosdakarya, 2013), hlm. 5.
} 
Model kurikulum terintegrasi lebih memandang bahwa suatu pokok bahasan dalam proses pendidikan harus terpadu secara menyeluruh. Keterpaduan ini dapat dicapai melalui keterpaduan antara disiplin ilmu atau mata pelajaran yang diperlukan sehingga tidak ada lagi batasan-batasan antara satu disiplin ilmu atau mata pelajaran dengan yang lainnya. ${ }^{6}$

Pendidikan di Indonesia saat ini terkesan memiliki paham dualisme yang kental antara ilmu-ilmu agama dan ilmu-ilmu umum. Antara ilmu-ilmu agama dan ilmu-ilmu umum seperti dipisahkan oleh jurang yang sangat lebar dengan paham dikotomi dalam ilmu-ilmu tersebut. Keberadaan pesantren dengan tipe yang beragam tentunya menjadi salah bagian dari kenyataan proses pendidikan saat ini. Dengan kurikulum pesantren yang dianggap masih klasik dan tidak relevan lagi dengan kebutuhan zaman modern, pesantren dianggap hanya mengajarkan ilmu-ilmu agama saja. Tetapi dalam perkembangannya pesantren saat ini tidak hanya memfokuskan proses dan sistem pembelajarannya mengkaji ilmu-ilmu agama saja. Banyak pesantren yang juga mendirikan lembaga formalnya seperti madrasa atau sekolah yang tentunya terintegrasi dengan pondok pesantren.

Berdasarkan permasalahan tersebut, fokus penelitian ini adalah pola pengembangan kurikulum terintegrasi yang digunakan oleh pondok pesantren Annida Al Islamy Bekasi. Pemilihan pondok pesantren Annida Al Islamy sebagai objek pembahsaan ini berdasarkan pertimbangan; 1) pada umumnya pesantren berdiri didaerah terpencil, tetapi Annida Al Islamy ini berlokasi di tengah kota dengan dinamika masyarakat yang sangat kompleks, 2) pesantren ini telah beridiri sejak tahun 1963 yang didirikan oleh KH. Muhammad Muhajirin Amsar Addary dengan mengadopsi kurikulum pendidikan islam al-Ghazali dan pembelajaran kooperatif antara siswa/santri dengan gurunya

\footnotetext{
${ }^{6}$ Muhammad Ali, Pengembangan Kurikulum di Sekolah, (Bandung: Sinar Baru Algesindo, 2009), hlm. 58.

- 154 -
}

Al Marhalah : Jurnal Pendidikan Islam. Volume. 14, No. 2 November 2018 
dengan memfokuskan keterampilan santri dalam mengkaji kitab kuning, 3) corak pendidikan pesantren di tanah betawi yang agak berbeda dengan tanah Pasundan atau tanah Jawa pada umumnya, 4) tidak hanya pendidikan non formal dalam bentuk lembaga pesantren, Annida Al Islamy juga memilki lembaga pendidikan formal yaitu Mts, MA, hingga Sekolah Tinggi Ilmu Tarbiyah. Penelitian ini bertujuan untuk mengkaji model kurikulum integrasi yang digunakan pesantren. Pendekatan yang digunakan yaitu pendekatan kualitatif dengan metode studi kasus. Pengumpulan data menggunakan metode observasi, wawancara, dan studi dokumentasi.

\section{Pembahasan}

\section{Profil Pondok Pesantren Annida Al Islamy Bekasi}

Pondok Pesantren Annida Al Islamy berlokasi di Jl. Ir. H. Juanda No. 124 A Bekasi Timur, lokasi tersebut berada ditengah kota bekasi yang merupakan jalan utama. Lokasi pesantren dengan madrasah tidak terlalu jauh, lokasi Madrasah tingkat Tsanawiyah, Aliyah, dan STIT berada di Jl. KH. Mas Mansyur No. 91 Bekasi Timur.

Pondok pesantren Annida Al Islamy didirikan oleh KH. Muhammad Muhajirin Amsar Addary pada tahun 1950 an, pada awalnya beliau merintis pondok pesantren yang berlokasi di jalan Ir. H. Juanda No 124 A,dengan melayani santri-santri yang tinggal dirumahnya. Pengakajian kitab-kitab kuning saat itu menggunakan metode sorogan atau CBSA (Cara Belajar Siswa Aktif), kemudian berkembang dengan mendirikan Madrasah pada tingkat Tsanawiyah, Aliyah dan Sekolah Tinggi Al Marhalah Al Ulya pada tahun 1963. Seiring perkembangannya pondok pesantren Annida Al Islamy yang mengembangkan pendidikan non formal dan formal yang saling terintegrasi antara pesantren dan madrasahnya dinaungi Yayasan Al Hanin. Hingga saat ini Annida Al Islamy menjadi lembaga pendidikan yang tetap 
eksis dan berpengaruh di daerah Kota Bekasi yang notabenenya merupakan kota penyanggah Ibu Kota yang sangat komplek dinamika kehidupan masyarakatnya.

Pondok Pesantren Annida Al Islamy tidak ketinggalan memperbaiki diri dan berinovasi dengan prinsip al-muhaafazhotu alal qodiimi al-shalih, wa al-akhdzu bil jadiidi al-ashlah (menjaga tradisi lama yang baik, dan menerima tradisi baru yang lebih baik). Visi pondok pesantren Annida Al Islamy yaitu Mewujudkan Sumber Daya Manusia yang Berakhlak Mulia yang Mampu Bersaing Secara Global. Sedangkan Misi nya yaitu; 1) Meningkatkan frekuensi dan kualitas kegiatan santri yang lebih menekankan pada pengembangan ilmu pengetahuan dan teknologi serta keimanan dan ketakwaan yang menunjang proses belajar mengajar dan menumbuhkembangkan disiplin pribadi siswa. 2) Menumbuhkembangkan nilai-nilai ketuhanan dan nilai-nilai kehidupan yang bersifat universal dan mengintegrasikannya dalam kehidupan, 3) Menerapkan manajemen partisipatif dengan melibatkan seluruh warga sekolah, Lembaga Swadaya Masyarakat, stake holders dan instansi serta institusi pendukung pendidikan lainnya. 4) Melaksanakan kegiatan belajar mengajar dengan mengedepankan potensi dan kecakapan generasi muda dalam membaca dan memahami kitab kuning dan literatur berbahasa Arab pada pengetahuan agama, disamping pengetahuan umum dan teknologi.

Sistem pendidikan di Pondok Pesantren Annida Al Islamy Bekasi mengintegrasikan pendidikan formal (MTs, MA, dan STIT) dengan sistem pendidikan diniyah non formal di Pondok Pesantren dengan pengkajian kitab kuning dengan sistem klasikal. Kemudian dalam upaya meningkatkan pengembangan diri siswa diadakan kegiatan-kegiatan melalui; 1) latihan Khitobah dan Pidato dalam Bahasa Indonesia, Arab dan Inggris, 2) latihan dan pembinaan Qiraat, Tahsin dan Tahfidz serta pembacaan Shalawat, 3) - 156 -

Al Marhalah : Jurnal Pendidikan Islam. Volume. 14, No. 2 November 2018 
pelatihan seni, marawis, nasyid, dan qasidah, 4) pelatihan olah raga dan pencak silat, 5) pelatihan Paskibraka dan Pramuka dan Marching Band, 6) pelatihan Agroteknologi dan pangan 7) Kursus Komputer, Bahasa Inggris, Bahasa Arab, dan KDK (Kelompok Diskusi Kelas), 8) pekan lomba kemampuan dan keterampilan santri, 9) Latihan Dasar Kepemimpinan Santri.

Staf pengajar di Pondok Pesantren Annida Al Islamy merupakan lulusan terbaik didikan KH Muhammad Muhajirin Amsar Addary semasa mereka menjadi santri di Ponpes Annida Al Islamy, kemudian mereka melanjutkan studi nya keberbagai perguruan tinggi berkualitas baik dalam negeri dan luar negeri. Staf pendidik juga merupakan anak dan menantu dari KH Muhammad Muhajirin Amsar Addary yang sangat kompeten dibidannya masing-masing. Para staf pengajar tidak hanya mengajar di pondok pesantren saja, tetapi juga mengajar di Madrasah baik Tsanawiyah ataupun Aliyah dan bahkan STIT. Hal ini menjadi salah satu upaya pengintegrasian antara kegiatan belajar mengajar di pondok pesantren dengan madrasah dan sekolah tinggi.

\section{Kurikulum Terintegrasi Pondok Pesantren Annida Al Islamy Bekasi}

Pelaksanaan pengembangan kurikulum yang terintegrasi menurut Khalid Rahman yaitu; a) Konsep Pengembangan Kurikulum terintegrasi terkandung dalam; 1) Konsepsi Visi dan Misi yang Terintegrasi, 2) Integrasi Kelembagaan, 3) Integrasi Kurikulum dan Pembelajaran. ${ }^{7}$

Berdasarkan pada hasil penelitian, penulis mengurai pengembangan kurikulum terintegrasi di Pondok Pesantren Annida Al-Islamy Bekasi yang kemudian dianalisis dengan kajian teori yang telah disinggung sebelumnya, sebagai berikut:

\footnotetext{
${ }^{7}$ Khalid Rahman, Pengembangan Kurikulum Terintegrasi di Sekolah/Madrasah, J-PAI, Vol. 1 No.1 Juli-Desember 2014.
} 
Wathroh Mursyidi

\section{Konsepsi Visi dan Misi yang Terintegrasi}

Pondok Pesantren Annida Al-Islamy dengan prinsip al-muhaafazhotu alal qodiimi al-shalih, wa al-akhdzu bil jadiidi al-ashlah (menjaga tradisi lama yang baik, dan menerima tradisi baru yang lebih baik). Dengan prinsip tersebut terlihat arah dan tujuan penyelenggaraan pendidikan berdasarkan AlQuran dan Hadits dengan memperhatikan tantangan zaman yang semakin beragaam. Visi pondok pesantren Annida Al Islamy yaitu Mewujudkan Sumber Daya Manusia yang Berakhlak Mulia yang Mampu Bersaing Secara Global. Sedangkan Misi nya yaitu; 1) Meningkatkan frekuensi dan kualitas kegiatan santri yang lebih menekankan pada pengembangan ilmu pengetahuan dan teknologi serta keimanan dan ketakwaan yang menunjang proses belajar mengajar dan menumbuhkembangkan disiplin pribadi siswa. 2) Menumbuhkembangkan nilai-nilai ketuhanan dan nilai-nilai kehidupan yang bersifat universal dan mengintegrasikannya dalam kehidupan, 3) Menerapkan manajemen partisipatif dengan melibatkan seluruh warga sekolah, Lembaga Swadaya Masyarakat, stake holders dan instansi serta institusi pendukung pendidikan lainnya. 4) Melaksanakan kegiatan belajar mengajar dengan mengedepankan potensi dan kecakapan generasi muda dalam membaca dan memahami kitab kuning dan literatur berbahasa Arab pada pengetahuan agama, disamping pengetahuan umum dan teknologi.

Visi dan misi di atas menjadi acuan dalam pengembangan kurikulum, bahwa untuk mengembangkan tujuan kurikulum harus merupakan bagian penurunan dari visi dan misi. Karena proses pengembangan kurikulum dimulai dengan visi dan misi lembaga (asumsi asumsi filosofis) sebagai sistem nilai atau padangan hidup. Berdasarkan visi dan misi itulah selanjutnya ditentukan tentang pengembangan struktur kurikulum sebagai 
arah pembentukan hakikat pengetahuan, sosiokultutral, kondisi peserta didik, dan perkembangan teori pembelajaran. ${ }^{8}$

Visi dan misi Pondok Pesanten Annida Al-Islamy sebagaimana yang telah dipaparkan, menunjukkan himmah integrasi sudah terlihat dari unsurunsur visi dan misi pondok pesantren yang berkeinginan untuk menciptakan sumber daya manusia yang berakhlak mulia yang mampu bersaing secara global dengan keimanan dan ketakwaan didalam di kehidupannya. Dan kemudian mengintegrasikan nilai ketuhanan dan nilai kehidupan dilengkapi dengan kemampuan berdasarkan potensi yang dimiliki santrinya. Dari visi dan misi inilah kemudian diturunkan dalam ranah praktis menjadi suatu kurikulum yang diberlakukan di Pondok Pesantren Annida Al Islamy Bekasi.

2. Integrasi Kelembagaan

Integrasi kelembagaan menurut Khalid Rahman yaitu sekolah/madrasah diharuskan memiliki asrama (boarding school/dormitory) yang keberadaanya berfungsi untuk menunjang kesuksesan pelaksanaan kurikulum dan pengembangannya. Pemahaman pentingnya ada asrama dilatarbelakangi kegiatan siswa selama 24 jam sehari bila diperinci siswa berada disekolah untuk belajar hanya menghabiskan waktu kurang lebih 8 jam, sedangkan 16 jam lainnya lebih banyak dihabiskan di rumah yang mana kemungkinan untuk belajar di rumah sangat sedikit. ${ }^{9}$

Desain kelembagaan yang terintegrasi di sekolah atau madrasah tidak terjadi dikotomi pengambilan kebijakan program akademik, sehingga program yang ada di sekolah dan asrama saling mendukung keberadaannya, saling memengaruhi, dan bahkan menjadi satu program yang tidak terpisahkan karena satu kesatuan. Tidak terjadi pemahaman ini program

\footnotetext{
${ }^{8}$ Wina Sanjaya, Kurikulum dan Pembelajaran: Teori dan Praktik Pengembangan Kurikulum Tingkat Satuan Pendidikan (KTSP), (Jakarta: Kencana, 2009), hlm. 36-37.

${ }^{9}$ Khalid Rahman, ibid., hlm. 27.
} 
asarama, dan ini program sekolah sehingga terkesan tanggung jawab program terpisah, tapi yang terjadi program asrama adalah program sekolah juga dan program sekolah juga program asrama, sehingga tidak ada beda.

Pondok Pesantren Annida Al Islamy Bekasi memiliki lembaga formal tingkat MTs, MA, dan STIT, yang semuanya terintegrasi dari mulai kebijakan program akademik dan program penunjang akademik lainnya. Durasi waktu yang terbatas di ruang kelas sekolah, dilengkapi dengan kegiatan di asrama atau pondok, yang tentunya melengkapi aktivitas akademik yang sudah terlaksana tetapi belum maksimal, atau yang belum terlaksana di sekolah karena keterbatasan ruang dan waktu.

3. Integrasi Kurikulum dan Pembelajaran

Integrasi kurikulum di sekolah/madrasah berlandaskan kurikulum nasional yang termaktub pada SNP tahun 2005 dan kurikulum internasional Cambridge atau CIE (Cambridge International Examination) Center bagi sekolah/madrasah yang menginginkan standar internasional demi tuntutan persaingan global, atau mungkin standar dari negara lain yang dianggap telah maju dalam bidang pendidikannya. Kurikulum terintegrasi yang dilaksanakan di sekolah/madrasah secara struktur formal, paling tidak terdapat tiga jenis, yaitu (a) integrasi kurikulum nasional (KTSP) dan internasional (IGCSE), (b) integrasi kurikulum intrakurikuler (KTSP/IGCSE)dan ekstrakurikuler (L2L/youth entrepreneurship program/adiwiyata/program dormitory), dan (c) integrasi kurikulum dalam pembelajaran (within sigle discipline, across several disciplines, dan inside the mind of the learner). ${ }^{10}$

Berdasarkan teori di atas, mengenai tipe pelaksanaan kurikulum yang terintegrasi. Pondok Pesantren Annida Al Islamy telah melaksanakan point b dan c secara garis besar. Walaupun pada pelaksanaan masih belum

\footnotetext{
${ }^{10}$ Khalid Rahman, 28.

- 160 -
}

Al Marhalah : Jurnal Pendidikan Islam. Volume. 14, No. 2 November 2018 
sepenuhnya memenuhi kriteria dari kedua atau ketiga tipe pelaksanaan kurikulum terintegrasi tersebut.

a. Perencanaan

Perencanaan pengembangan kurikulum terintegrasi yang dilakukan di sekolah/madrasah harus diawali dengan penyelenggaraan workshop pengembangan kurikulum secara tahunan. Perencanaan kurikulum mengacu dari visi misi lembaga, yang penekanannya pada pembentukan kepribadian yang berdaya saing baik nasional maupun internasional, penanaman nilainilai kepemimpinan dan pengembangan kreativitas atau skill peserta didik yang dimilikinya.

Kepala sekolah sesuai dengan perannya sebagai manajer sekolah menitikberatkan pada perencanaan untuk melaksanakan kurikulum dalam sistem sekolah, melakukan koordinasi kegiatan guru-guru, menata dan membina organisasi guru dan organisasi pembelajaran peserta didik, membina sistem komunikasi yang efektif di lingkungan sekolah antara sekolah dan masyarakat serta lembaga-lembaga lainnya, melakukan supervisi bagi guru-guru bidang studi dan menilai kegiatan guru-guru serta melaksanakan penilaian secara keseluruhannya. ${ }^{11}$

Sedangkan tugas guru menyusun perencanaan kegiatan tahunan, semester, bulanan, dan mingguan yang terkait dalam pelaksanaan instruksional dalam bidang studi atau kelas yang menjadi tanggung jawabnya. Dalam perencanaan kurikulum sekolah/madrasah bila diklasifikasi melahirkan kurikulum terintegrasi yang mengemas written curriculum, experencial curriculum dan hidden curriculum yang dilaksanakan secara sinergis, meskipun pelaksanaannya sekolah melakukan modifikasi

\footnotetext{
${ }^{11}$ Oemar Hamalik, Manajemen Pengembangan Kurikulum, (Bandung: UPI dan PT Remaja Rosdakarya, 2008), hlm. 173.
} 
Dari pemaparan teori diatas berhubungan dengan hasil wawancara yang penulis lakukan di Pondok Pesantren Annida Al Islamy Bekasi setiap tahun ajaran baru memulai kegiatan pendidikan dengan menyelenggarakan rapat koordinasi secara terintegrasi antara pihak pesantren maupun madrasah serta pihak yayasan. Meliputi seluruh pimpinan, staf kependidikan dan pendidik. Hal ini dilakukan salah satunya bertujuan untuk membahas pengembangan kurikulum Pondok Pesantren Annida Al Islamy mengacu dari visi dan misi yang kemudian penekanannya pada pembentukan sumber daya manusia yang cerdas secara spiritual, intelektual dan sosial. Dengan adanya kegiatan ini menjadi satu bentuk upaya awal perencanaan yang baik dalam berlangsungnya kegiatan pendidikan secara umum, dan khususnya dalam aspek kurikulum Pondok Pesantren. ${ }^{12}$

b. Pelaksanaan

Pembelajaran di kelas yang dilakukan di sekolah/madrasah, bila dipilah sesuai model pengembangan kurikulum terintegrasi akan terpetakan secara mudah. Beberapa bagian kurikulum terintegrasi bisa dilaksanakan secara fleksibel di dormitory (asrama), bahwa ada kegiatan akademik yang dilaksanakan di asrama dan yang bisa menunjang kurikulum yang dilaksanakan sekolah untuk mencapai visi, misi dan tujuan sekolah seperti pelatihan dan bimbingan leadership secara intensif, pelatihan dan pembinaan kewirausahaan yang dipraktekkan secara intensif, dan kegiatan lainnya guna membentuk dan membina watak kepribadian dan akhlak mulia selama di asrama. Dengan demikian, proses pembelajaran tidak membuat siswa jenuh hanya dengan satu setting di kelas saja. Pelaksanaan kurikulum terintegrasi

\footnotetext{
${ }^{12}$ Hasil wawancara dengan pimpinan pondok, para asâtidz dan staf administrasi pada tanggal 7 November 2016.

-162 -
}

Al Marhalah : Jurnal Pendidikan Islam. Volume. 14, No. 2 November 2018 
lebih variatif dan banyak menggabungkan berbagai strategi dan metode pembelajaran. ${ }^{13}$

Berdasarkan teori yang telah dipaparkan bersesuain dengan informasi yang penulis dapatkan, bila dicermati lebih mendalam pelaksanaan kurikulum di Pondok Pesantren Annida Al Islamy direalisasikan dengan kegiatan-kegiatan yang saling menunjang antara pembelajaran di madrasah dan di pondok pesantren. Seperti dengan adanya mata pelajaran di madrasah yang tidak memadai dari aspek situasi dan kondisinya bisa disajikan di pondok pesantren begitu pula sebaliknya. Kegitan-kegiatan lainnya yang menunjang untuk terlaksananya visi dan misi pondok pesantren yaitu diadakannya kegiatan LDKS (Latihan Dasar Kepemimpinan Santri) yang dilaksanakan setiap tahun, Pelatihan Hidro Ponik, Pekan Tata Boga, Koperasi Pesantren, dan kegiatan Kerja Bakti dengan masyarakat sekitar yang biasa dilaksanakan setiap hari minggu. Dan tentunya kurikulum yang biasa dilaksanakan di pondok pesantren pada umumnya, seperti latihan Khitobah, Qari, Barzanji, dan KDK (Kelompok Diskusi Kelas) yaitu kegiatan kelompok belajar atau diskusi dengan kajian-kajian tertentu yang dapat dipilih oleh para santri, meliputi English club, Arabic club, Fahmil Quran dan Kitab-kitab kuning.

c. Evaluasi

Tujuan pendidikan beserta kebijakan-kebijakan penyertanya merupakan acuan dari proses evaluasi yang dilaksanakan. Begitu pula Muhammad Ali berpendapat, bahwa evaluasi kurikulum harus mengacu pada prinsip: (1) evaluasi mengacu pada tujuan (2) evaluasi bersifat komprehensif dan (3) evaluasi dilaksanakan secara objektif. ${ }^{14}$

\footnotetext{
${ }^{13}$ Khalid Rahman, 41.

${ }^{14}$ Muhammad Ali, 127.
} 
Penilaian komprehensif dilakukan tidak hanya pada ruangan kelas tetapi juga pada proses pembelajaran di luar kelas, atau bahkan berdasar pada penilaian teman sejawat yang dilakukan siswa sendiri dengan adanya student advisor.

Peranan evaluasi kurikulum bagi pimpinan, berkenaan dengan hal yaitu: evaluasi sebagai moral judgement, evaluasi dan penentuan keputusan, serta evaluasi dan konsensus nilai. ${ }^{15}$ Dari peranan kepemimpinan ini dijadikan feedback untuk menyusun perencanaan kurikulum terintegrasi selanjutnya. Bagi guru, penyelenggaraan evaluasi hasil penerapan pengembangan kurikulum dalam satu semester, yaitu: evaluasi formatif dan evaluasi sumatif. Evaluasi formatif dan sumatif itu dilaksanakan dengan bentuk penilaian tes, baik tulis, praktek maupun portofolio. Guru dalam melakukan evaluasi harus menggunakan pedoman berbentuk form untuk memetakan ranah apa saja yang akan dievaluasi dari peserta didik. ${ }^{16}$

Evaluasi pendidikan yang dilaksanakan di Pondok Pesantren Annida Al Islamy pada lembaga Madrasan Tsanawiyah dan Aliyah melakukan evaluasi formatif dan sumatif sebagaimana yang dilaksanakan di madrasahmadrasah di Indonesia pada umumnya, mengacu pada kurikulum KTSP dan Kur 2013. Sedangkan bentuk evaluasi yang digunakan di pondok pesantren tidak sepenuhnya memenuhi standar evaluasi formatif atau sumatif, karena sistem evaluasi pembelajaran atau biasa disebut pengajian di pondok pesantren mengacu pada standarisasi yang dibuat oleh para kyai dan asatidz. Ketika ada santri yang dirasa belum mampu menguasai suatu materi sesuai dengan tingkatan kelasnya, santri terebut dipersilahkan mengikuti kelas yang lebih dasar di bawah posisi kelas santri tersebut berada. Atau para asatidz menyediakan kelompok belajar dan staf pengajar khusus yang melayani para

\footnotetext{
${ }^{15}$ Nana Syaodih Sukmadinata, 180.

${ }^{16}$ Suharsimi Arikunto, Prosedur Penelitian: Suatu Pendekatan Praktis, (Jakarta: PT Bima Karya, 1987), hlm. 142

- 164 -
}

Al Marhalah : Jurnal Pendidikan Islam. Volume. 14, No. 2 November 2018 
santri yang membutuhkan pembelajaran khusus untuk mendalami suatu materi tertentu. ${ }^{17}$

\section{Simpulan}

Menurut Beauchamp Kurikulum adalah "A curriculum is a written document which may contain many ingredients, but basically it is a plan for the education of pupils during theie enrollment in given school". Beauchamp lebih memberikan tekanan bahwa kurikulum adalah suatu rencana pendidikan atau pengajaran.

Model kurikulum terintegrasi lebih memandang bahwa suatu pokok bahasan dalam proses pendidikan harus terpadu secara menyeluruh. Keterpaduan ini dapat dicapai melalui keterpaduan antara disiplin ilmu atau mata pelajaran yang diperlukan sehingga tidak ada lagi batasan-batasan antara satu disiplin ilmu atau mata pelajaran dengan yang lainnya

Pondok Pesantren adalah lembaga pendidikan Islam tertua yang merupakan produk budaya Indonesia. Keberadaan Pesantren di Indonesia dimulai sejak Islam masuk negeri ini dengan mengadopsi sistem pendidikan keagamaan yang sebenarnya telah lama berkembang sebelum kedatangan Islam.Sebagai lembaga pendidikan yang telah lama berurat akar di negeri ini, pondok pesantren diakui memiliki andil yang sangat besar terhadap perjalanan sejarah bangsa. ${ }^{18}$

Pada awal abad kedua puluhan, unsur baru berupa sistem pendidikan klasikal mulai memasuki pesantren. Sejalan dengan perkembangan dan perubahan bentuk pesantren, Menteri Agama RI. Mengeluarkan peraturan nomor 3 tahun 1979, yang mengklasifikasikan pondok pesantren. Salah

\footnotetext{
${ }^{17}$ Hasil wawancara dengan pimpinan pondok, para asâtidz dan staf administrasi pada tanggal 8 November 2016

${ }^{18}$ Haedari, H.Amin. Transformasi Pesantren, (Jakarta: Media Nusantara, 2007), hlm. 3 
Wathroh Mursyidi

satunya Pondok Pesantren tipe D, yaitu yang menyelenggarakan sistem pondok pesantren dan sekaligus sistem sekolah atau madrasah.

Sistem pendidikan di Pondok Pesantren Annida Al Islamy Bekasi mengintegrasikan pendidikan formal (MTs, MA, dan STIT) dengan sistem pendidikan diniyah non formal di Pondok Pesantren dengan pengkajian kitab kuning dengan sistem klasikal. Pelaksanaan pengembangan kurikulum yang terintegrasi menurut Khalid Rahman yaitu; a) Konsep Pengembangan Kurikulum terintegrasi terkandung dalam; 1) Konsepsi Visi dan Misi yang Terintegrasi, 2) Integrasi Kelembagaan, 3) Integrasi Kurikulum dan Pembelajaran. ${ }^{19}$

Berdasarkan pada hasil penelitian, penulis mengurai pengembangan kurikulum terintegrasi di Pondok Pesantren Annida Al-Islamy Bekasi yang kemudian dianalisis dengan kajian teori yang telah disinggung sebelumnya. Pondok Pesantren Annida Al Islamy secara umum telah melaksanakan pengembangan kurikulum terintegrasi, tetapi masih banyak aspek yang belum sepenuhnya terpenuhi. Dengan demikian, penelitian ini menjadi acuan sebagai penelitian selanjutnya tentang kurikulum terintegrasi yang diterapkan pada Pondok Pesantren di Indonesia sebagai salah satu lembaga formal dan non formal.

\section{Daftar Pustaka}

Fatah, H Rohadi Abdul, Taufik, M Tata, Bisri, Abdul Mukti. (2005). Rekontruksi Pesantren Masa Depan, Jakarta Utara: PT. Listafariska Putra.

Haedari, H.Amin. (2007).Transformasi Pesantren, Jakarta: Media Nusantara.

Hielmy, Irfan. (2000). Wancana Islam. Ciamis:Pusat Informasi Pesantren.

\footnotetext{
${ }^{19}$ Khalid Rahman, Pengembangan Kurikulum Terintegrasi di Sekolah/Madrasah, J-PAI, Vol. 1 No.1 Juli-Desember 2014.

- 166 -
}

Al Marhalah : Jurnal Pendidikan Islam. Volume. 14, No. 2 November 2018 
Kurikulum Terintegrasi di Pondok Pesantren Annida Al Islamy Bekasi

Khalid Rahman, Pengembangan Kurikulum Terintegrasi di Sekolah/Madrasah, J-PAI, Vol. 1 No.1 Juli-Desember 2014.

Muhammad Ali. (2009). Pengembangan Kurikulum di Sekolah, Bandung: Sinar Baru Algesindo.

Nana Syaodih Sukmadinata. (2013). Pengembangan Kurikulum: Teori dan Praktek. Bandung: Remaja Rosdakarya.

Nurcholis Madjid. (1997). Bilik-Bilik Pesantren Sebuah Potret Perjalanan. Jakarta: Paramadina.

Oemar Hamalik. (2008). Manajemen Pengembangan Kurikulum. Bandung: UPI dan PT Remaja Rosdakarya.

Suharsimi Arikunto. (1987). Prosedur Penelitian: Suatu Pendekatan Praktis, Jakarta: PT Bima Karya.

Wina Sanjaya. (2009). Kurikulum dan Pembelajaran: Teori dan Praktik Pengembangan Kurikulum Tingkat Satuan Pendidikan (KTSP). Jakarta: Kencana. 